\section{Pooh has an addiction issue: holiday reading}

Winnie the Pooh is addicted to honey.' He doesn't need psychostimulants (also addicting) but, rather, rehabilitation and maybe some methadone. His mind is little, not because of shaken bear syndrome, but because the honey is rotting his brain cells. His lack of focus, poorly laid out plans and behaviour (attention deficit disorder), as well as his weight, are also a result of the addiction. $\mathrm{He}$ spends his entire day looking for honey, bothering other characters for their honey, getting into trouble because of the honey and even fearing imaginary creatures (the Heffalumps) because he's tripping on the honey. Look in Pooh's home, and I'm sure you will find a bunch of empty jars of honey.

Owl has mild autism. He monologues, is socially awkward and has special interests (such as books) and so forth. Piglet suffers from many phobias. He won't leave the house if Pooh doesn't drag him out. He's afraid of everything.

This summarizes the major psychological disorders:

- Pooh: addiction

- Owl: mild autism

- Piglet: phobias

- Eyore: depression

- Tigger: attention deficit hyperactivity disorder

- Rabbit: need to control others.

Mary R. Wisely

\section{REFERENCE}

1. Shea SE, Gordon K, Hawkins A, et al. Pathology in the Hundred Acre Wood: a neurodevelopmental perspective on A.A. Milne. CMAJ 2000;163:1557-9.

For the full letter, go to: www.cmaj.ca/cgi/eletters /163/12/1557\#5452365

DOI: $10.1503 / \mathrm{cmaj} .110-2086$

\section{The crime of mental illness}

The editorial by MacDonald and colleagues is welcome for its condemnation of a situation that shows the total inadequacy of our mental health services. ${ }^{1}$ To incarcerate patients in jails for offences that are due to illness goes beyond Dickensian.

The authors suggest no remedy of any substance. Destigmatization, advocacy by the mental health profession, more studies and better training of corrections staff: all pious wishes. But why train corrections staff to deal with a population that should not even be there?

I am a retired psychiatrist whose career goes back far enough that I can remember the old mental hospitals. They had many awful characteristics, but instead of reforming them, we destroyed them. Many people were successfully returned to the community, but a large residuum who were essentially untreatable and extremely vulnerable were simply dumped on an unwelcoming community. And there they remain, except when they are bundled into prison for want of a better alternative.

This situation demands action now, and I believe that we need to go back to the original concept of "asylum" (i.e., protection) for people who have little hope of being incorporated successfully into society. We have surely learned enough in the past 50 years to be able to design and staff humane establishments that would protect mentally ill patients who are being unjustifiably criminalized. Surely we could develop techniques that recognize treatability where it is present and allow a person to leave an institution with dignity after suitable care.

If anyone has a better suggestion, then for pity's sake, make it. Mine may not be the best, bit I do think it is practicable.

\section{Alistair Munro MD}

Dalhousie University (Emeritus), Eastern

Passage, NS

\section{REFERENCE}

1. MacDonald N, Hucker SJ, Hébert PC. The crime of mental illness. CMAJ 2010;182:1399.

For the full letter, go to: www.cmaj.ca/cgi/eletters $/ 182 / 13 / 1399$

DOI: 10.1503/cmaj.110-2130

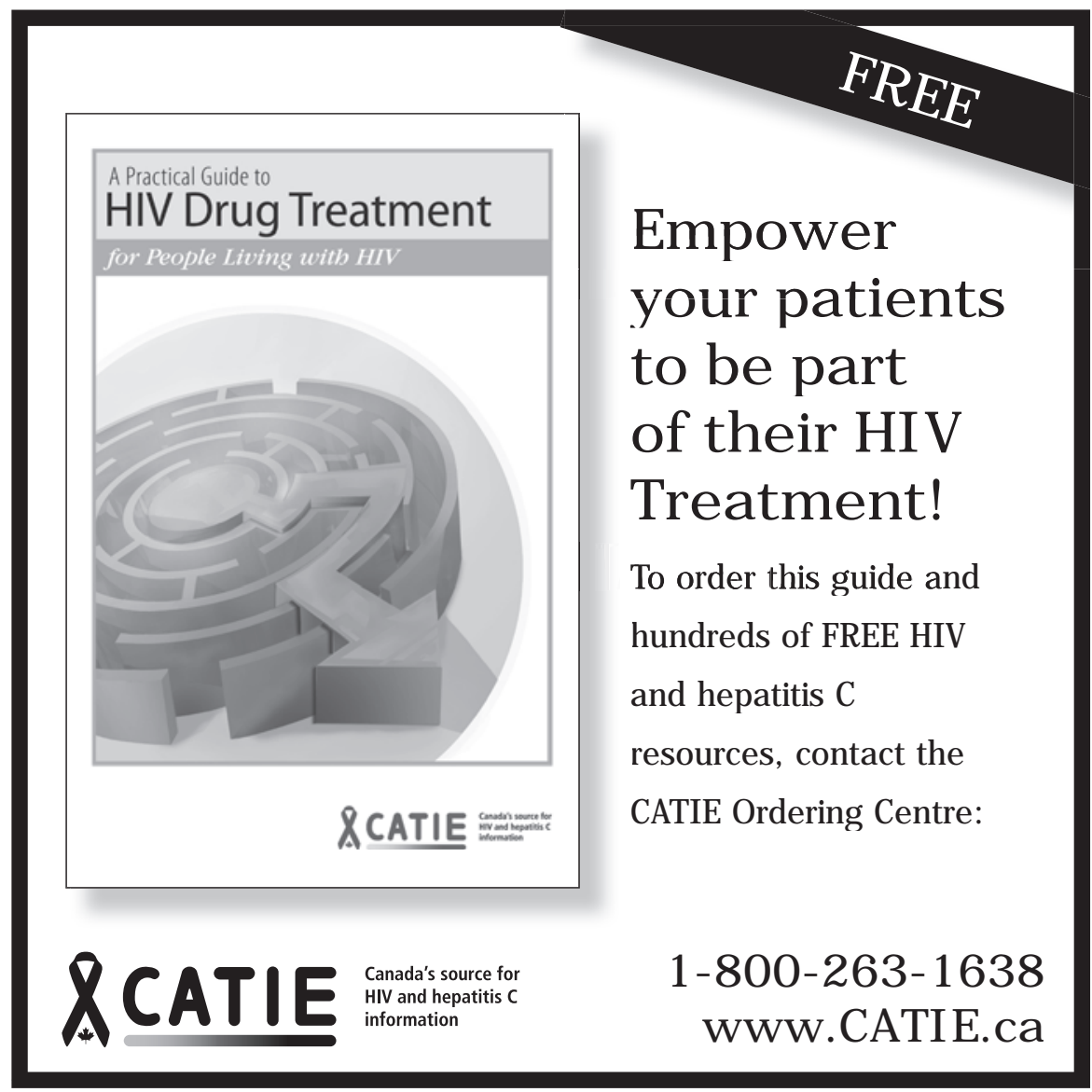

